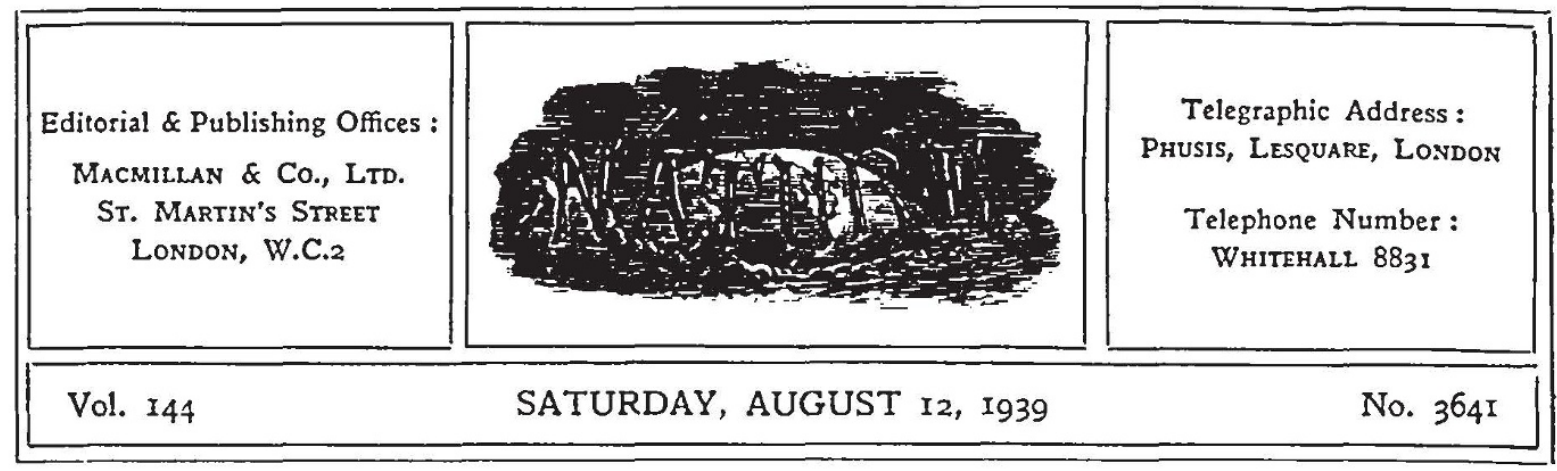

\title{
CONSERVATION OF ANTIQUITIES IN BRITISH DEPENDENCIES
}

$T^{\prime}$ HE Trustees of the British Museum (Bloomsbury) are to be congratulated on the acquisition of the remarkably fine bronze head from Southern Nigeria, to which reference was made in Nature of July 15, p. 106 . Not only is this an outstanding example of the highly developed artistic products of early West African culture, but also it belongs to a class of objects to which additions available for study in European collections are likely to be restricted in number in future. Since the beginning of the century, and arising possibly in a great measure from the publication of the bronzes and other artistic objects from Benin in the Pitt-Rivers collections, interest in and appreciation of the merits of the various schools of sculptural art native to African culture has increased rapidly and become widespread. In consequence, a number of characteristic examples, and many of exceptional merit, have been brought to Europe by collectors. During the past twenty years it has been known that bronze heads of remarkable character have been found from time to tine in the course of excavation at Ifé in the Yoruba country of Southern Nigeria; but the discovery there in 1938 of a number of such examples of the artistic skill of an ancient and forgotten people, of which this British Museum acquisition is one, has quickened interest in these and similar objects of "high antiquity, artistic merit, and uncertain cultural origin", and as a result has induced those in authority to take steps to sccure that West Africa should not be denuded of such interesting and important relics of its past.

In January 1939 the Government of Nigeria made an Order in Council enabling the Governor of Nigeria to control the export of antique African sculptural works of art; and since then the native authority of Ifé has taken action to protect the antiquities in the area under its administration. Such interest on the part of a native administration suggests that the subsequent action of the Secretary of State for the Colonies, announced in "The Colonial Empire" (the statement recently issued with the estimates for 1939) by which he has instituted inquiries with a view to the enactment of legislation throughout West Africa to secure the protection of indigenous African objects of ethnological import or esthetic interest, will reccive strong backing from a quarter which might not have been anticipated. It should ensure that any legislation which may be framed as a result of the inquiry will not become a deadletter.

It is interesting to note that the Colonial Office, which frequently in the past has been accused of inertia when matters of moment to the scientific pursuit of cultural studies have been at stake, is now ready to give due heed to their interest and importance when attention has been directed to them. In Mr. MacDonald's own words: "Wherever such discoveries have been made His Majesty's Government has a keen interest in revealing them, and in preserving them, both on account of their scientific and historical ralue to scholarship, and on account of the sus. ceptibilities of the local people, who naturally tend to regard these evidences of their cultural origins with reverence and pride".

It is in accordance with this policy that the 
study of antiquities is fostered and their conservation has been taken actively in hand by the authorities in sereral of the dependencies under legislative enactment. In Palestine, for example, which for the student of early racial and cultural history, afart from its bearing on the origins of the Christian religion, now holds a forcmost place among the regions of major interest and significance for scientific research, not only does the Government direct the course of investigation by the exercise of its authority, acting under skilled advice, but a'so through the Department of Antiquities is itself engaged in investigation. In addition to the archrological work which has been carried out under licence, the study of the past history of Palestine has benefited by the activitics of the Department of Antiquities in the field.

The importance of Palestine in the historic development of modern civilization naturally tends to attract to it investigators from outside, drawn from all parts of the world; and Jerusalem, equipped as it is with University, Antiquities Department, and the headquarters of several national schools of archreological research, since the War, and since the termination of the British mandate in Iraq, has become by far the most important centre of archæological interest under British jurisdiction. It is, however, by no means the only one ; and if it were only possible to ensure more adequate financial provision, both Malta and Cyprus in their respective fields of archro. logical and historical interest might make a fair bid to become not unworthy rivals of the Holy Land. In Nalta in particular, remarkable prehistoric remains and culture present a number of problems to the archæologist, which still await solution. Here a notable step in advance has been taken by the foundation of a professorship in archæology at the Royal University of Malta, which it is hoped, in the words of Mr. MacDonald's report, "will prove a starting point for a more exhaustive development of Malta's archrological realth". A survey of the monuments of the island is projected. This is a measure which has been too long delayed; and although the visitor to the island, who views the remarkable prehistoric structures which form one of its attractions and examines the archrological collections in the Museum, will appreciate the devoted service to archæological studies in Malta over many years of the late Sir 'Th. Zammit, the net result for the disccrning is an uneasy feeling that too little support has been given to the investigation of a culture that in its way is unique. It is indeed to be hoped that a better day is dawning. MIr. MacDonald announces that the curator of the archrological section of the Museum has been on study leave in Furope, and after working on sites in England is proceeding to Rome and Athens.

Cyprus, an island rich in historic associations, as it is in antiquities, has in the past been much hampered by financial considerations; and these, notwithstanding assistance from private sources interested in the past history of the island, have not been entirely overcome. The work of the preservation of the ancient monuments of Cyprus nevertheless continues. In addition to the amount spent from the funds of the Government of Cyprus, generous assistance has been given towards this work by Lord Mersey's Cyprús Committee and by the Carnegie Corporation. Among the more important of the monuments to which attention has been given are the Castle of St. Hilarion, Bellapais Abbey, and the fortifications of Famagusta. In this work the Cyprus authorities have had the co-operation of the Office of Works, an official having been seconded from England to the Cyprus Department of Antiquities as superintendent of works, who has trained a Cypriote official to undertake this function after his own return to England.

In the conservation of antiquities, however, anything approaching safety is to be won only at the price of constant rigilance. In this connexion, it is interesting to find that in Antiquity of June, the editor, in directing the attention of his readers to a communication from Mr. Stewart Perowne, dealing with two ancient city sites of remarkable archæological interest examined by him in the Aden Protectorate, urges strongly the need for the appointment, without delay, of a Director of Antiquities for the Protectorate. He supports his argument by reference to the importance for archiological studies of this area, as indicated not only in the results recorded by Mr. Perowne, as well as those obtained by Miss G. Caton Thomp. son, Miss E. Gardner, Miss Freya Stark and others, but also by pointing out the imminent dangers of spoliation, if future exploration is not properly supervised, and adequate measures are not taken to protect the monuments and house the smaller finds of archæological research. There can be no question that the editor of Antiquity is right in thinking that archrological opinion in Great Britain is with him in this matter. 